\title{
The Evaluation of My Home My Village Method to Support the Complete Basic Immunization Programme in Surabaya, Indonesia
}

\author{
Fariani Syahrul $^{1}$, Hario Megatsari ${ }^{2}$, Ratna Dwi Wulandari ${ }^{3}$, Arief Hargono ${ }^{4}$, Kurnia Dwi Artanti ${ }^{4}$ \\ ${ }^{1}$ Lecturer in Department of Epidemiology, ${ }^{2}$ Lecturer in Department of Health Promotion and Behavior \\ Sciences, ${ }^{3}$ Lecturer in Department of Health Policy and Administration, ${ }^{4}$ Lecturer in Department of \\ Epidemiology, Faculty of Public Health, Universitas Airlangga, Campus C Mulyorejo 60115, Surabaya- \\ Indonesia
}

\begin{abstract}
Introduction: The My Village My Home (MVMH) community-level tool was designed by the Maternal and Child Health Integrated Program (MCHIP) to provide the community and local health functionaries are a visual depiction of the immunization status of all infants born in a village. It ensures that every child receives immunization they need. In Indonesia, MVMH tool is used at the community level (called "Posyandu"). This research objectives is to evaluate My Village My Home (MVMH) method. It supports the Complete Basic Immunization Programme in Surabaya, Indonesia.
\end{abstract}

Method: This research was an observational study with cohort retrospective design. The exposure population of this research was Public Health Center (PHC) that has received MVMH training on March-April 2018 and the non exposure population of this research was PHC that has not received MVMH training yet. It was determined by using simple random sampling.

Results: $80 \%$ of cadres in the group that had received prior training were well-informed and in the group that did not get training $85 \%$ had good knowledge of $5 \%$ enough, $10 \%$ less. Knowledge of mothers in the cadre group who received training was $85 \%$ good and in the group of cadres who did not get $75 \%$ good training. Both cadres and mothers in the group of cadres who received training and did not receive training had a good attitude.

Conclusion: Most of the cadre with or without training and mothers have good knowledge. They have a good attitude towards the My Village My Home.

Keywords: Evaluation, Immunization, My Village My Home.

\section{Introduction}

The incidence of Vaccine Preventable Disease with immunization such as measles in the East Java Province is still relatively high. It includes the number of measles cases suspects cases and positive measles cases ${ }^{11}$. The East Java Provincial Health Office data shows that the

\section{Corresponding Author:}

Fariani Syahrul

Lecturer in Department of Epidemiology

Faculty of Public Health, Universitas Airlangga

Campus C Mulyorejo 60115, Surabaya-Indonesia

Email: fariani.s@fkm.unair.ac.id measles suspect cases were still found from 2012 to 2016 and continues increasingly. The highest measles suspect cases were recorded in 2016, amounting to 3,506 cases, and the lowest cases were recorded in 2012 with 398 cases. Numbers of positive measles cases are increase $\mathrm{e}^{2-3)}$.

Immunization is one of the most cost-effective public health interventions to prevent children from contracting vaccine-preventable diseases. Indonesia launched the Expanded Program for Immunization (EPI) in 1977. However, immunization coverage remains far below the United Nations International Children's Emergency Fun (UNICEF) and World Health Organization (WHO) target of $80 \%{ }^{4-5)}$. 
Low vaccination coverage often reflected services that were not easily accessible, uncomfortable, unreliable, or unfriendly officers. It may also be related to a lack of public trust in 18 vaccination and/ or vaccination services ${ }^{6}$. The level of vaccination coverage in a given community depends on both service factors and the degree to which the public trust in immunization services ${ }^{7)}$. Most interventions purpose to raise vaccination coverage focus on improving services or on informing and motivating families ${ }^{6}$.

The My Village My Home (MVMH) communitylevel tool is designed by the Maternal and Child Health Integrated Program (MCHIP) to provide the community and local health functionaries a visual depiction of the immunization status of all infants born in a village to ensure that every child receives every immunization they need. The MVMH tool designed for use at the community level by field-level workers, such as Auxiliary Nurse Midwives, Accredited Social Health Activists, and the community to efficiently and accurately track children's immunization status ${ }^{8}$. In Indonesia, MVMH tool used at the community level (called "Posyandu") by under supervised immunization coordinator cadre at Public Health Center. The community leaders, cadres, volunteers, and health workers are allowed by MVMH to monitor the vaccination status of every young child in participating communities and reminder guiding, and motivational visits.

The MVMH shows information on all children less than 2 years of age in a community under the roof of a house. Each row (from bottom to top), composed of boxes, is indicative of one beneficiary, abd each box indicates an antigen that is to be provided to the beneficiary ${ }^{9}$.

The objective research is to evaluate My Village My Home (MVMH) method, and to support the complete Basic Immunization Programme in Surabaya, Indonesia.

\section{Method}

This research was an observational study with cohort retrospective design. It was conducted in Surabaya, since September to December 2018.

The Public Health Center (PHC) was the exposure population of this research that has received MVMH training from Faculty of Public Health Universitas Airlangga on March-April 2018 and the non exposure population of this research was Public Health Center that has not received MVMH training yet. The MVMH tool is a large poster-sized record on which every infant in a community has his or her own row, with spaces for the child's name, date of birth, and dates of each vaccination 6). Respondents were 60 cadres and 60 mother with children under 2 years in Surabaya. The number of exposure samples used in this research was $10 \mathrm{PHC}$ and non exposure samples was $40 \mathrm{PHC}$. It was determined using simple random sampling technique.

The data that had been collected was in form of primary data, that it was obtained from an interview between the cadres and mother of children under 2 years with questionnaires. Before the interview taken, respondents would be given this research explanation, they were asked to sign the informed consent. Prior to the interview, respondents were given an explanation and then asked to sign an informed consent. Then, the data that had been collected were analyzed descriptively and it was presented in the form of narration and tables that illustrated the investigated variables.

\section{Results}

The result of this research was the socio-demographic characteristics cadre and mother with children under 2 years, descriptive analyze for input, process and output components about My Village My Home in Surabaya.

Socio-Demographic Characteristics: The average age of mothers is 32.67 years with a range of 21-54 years, while the average age of Posyandu cadres is 47.58 years with a range of 25-68 years. Age distribution of respondents can be seen in table 1 .

Table 1: Distribution of cadre and mother with children under 2 years based on age in Surabaya, 2018

\begin{tabular}{|c|c|c|}
\hline \multicolumn{1}{|c|}{ Age (years) } & n & \% \\
\hline Cadre & 2 & 3.3 \\
\hline $20-30$ & 10 & 1.7 \\
\hline $31-40$ & 23 & 38.3 \\
\hline $41-50$ & 19 & 31.7 \\
\hline $51-60$ & 6 & 10.0 \\
\hline $61-70$ & 60 & 100.0 \\
\hline Total & & \\
\hline Mother & 27 & 45.0 \\
\hline $20-30$ & 27 & 45.0 \\
\hline $31-40$ & 4 & 6.7 \\
\hline $41-50$ & 2 & 3.3 \\
\hline $51-60$ & 0 & 0 \\
\hline $61-70$ & 60 & 100.0 \\
\hline Total &
\end{tabular}


Descriptive Analysis for Input Components from the My Village My Home: The input component for Human Resources described is the knowledge of cadres and mothers about the MVMH. Cadre's knowledge about MVMH was measured using 8 questions with a choice of right or wrong answers.

Table 2: Distribution of Knowledge about MVMH in Surabaya, 2018

\begin{tabular}{|c|c|c|c|c|}
\hline \multirow{2}{*}{ Level } & \multicolumn{2}{|c|}{ Exposure Group } & \multicolumn{2}{c|}{$\begin{array}{c}\text { Non Exposure } \\
\text { Group }\end{array}$} \\
\cline { 2 - 5 } & $\mathbf{n}$ & $\mathbf{\%}$ & $\mathbf{n}$ & $\mathbf{\%}$ \\
\hline Cadre: & \multicolumn{3}{|c|}{} \\
\hline Hight & 16 & 80.0 & 36 & 90.0 \\
\hline Middle & 4 & 20.0 & 2 & 5.0 \\
\hline Low & 0 & 0 & 2 & 5.0 \\
\hline Total & 20 & 100.0 & 40 & 100.0 \\
\hline Mother: & \multicolumn{5}{|}{} \\
\hline Known & 18 & 90.0 & 20 & 50.0 \\
\hline Unknown & 2 & 10.0 & 20 & 50.0 \\
\hline Total & 20 & 100.0 & 40 & 100.0 \\
\hline
\end{tabular}

The results showed that cadres in both groups mostly had good knowledge about. But there are still less knowledgeable cadres.

Facilities and infrastructure referred to here are MVMH Sheets (seen from the quantity and quality), stationery to fill the MVMH, board or area to attach to the MVMH. More information is presented in table 3 the following.

Table 3: Distribution of MVMH media facilities and infrastructure in Surabaya, 2018

\begin{tabular}{|c|c|c|c|c|}
\hline \multirow{2}{*}{$\begin{array}{c}\text { MVMH } \\
\text { Media }\end{array}$} & \multicolumn{2}{|c|}{ Exposure Group } & \multicolumn{2}{c|}{$\begin{array}{c}\text { Non Exposure } \\
\text { Group }\end{array}$} \\
\cline { 2 - 5 } & $\mathbf{n}$ & $\%$ & $\mathbf{n}$ & $\%$ \\
\hline Avaibility: & \multicolumn{5}{|c|}{} \\
\hline Yes & 19 & 100.0 & 38 & 100.0 \\
\hline No & 0 & 0 & 0 & 0 \\
\hline Total & 19 & 100.0 & 38 & 100.0 \\
\hline Amount \& Quality according to standards \\
\hline Yes & 17 & 89.5 & 32 & 84.2 \\
\hline No & 2 & 10.5 & 6 & 15.8 \\
\hline Total & 19 & 100.0 & 38 & 100.0 \\
\hline Availability of space to attach MVMH media \\
\hline Yes & 19 & 100.0 & 27 & 71.1 \\
\hline No & 0 & 0 & 11 & 28.9 \\
\hline Total & 19 & 100.0 & 38 & 100.0 \\
\hline
\end{tabular}

The results showed that all cadres in the two groups said that the MVMH was available at the Posyandu. The number and quality are in accordance with the standard. Posyandu still exists that does not have an area to attach to the Immunization House during the Posyandu schedule. In this study also identified the availability of the MVMH budget in each Puskesmas that was the location of the study. Most cadres said that the source of the budget came from the Puskesmas and was adequate.

Indeed the procurement of MVMH from the Puskesmas. A cadre who said that there was a budget from community self-help, was intended for stationery to fill in the columns in the MVMH.

Table 4: Distribution of Budget Availability for MVMH in Surabaya, 2018

\begin{tabular}{|c|c|c|c|c|}
\hline \multirow{2}{*}{ Budget } & \multicolumn{2}{|c|}{ Exposure Group } & \multicolumn{2}{c|}{$\begin{array}{c}\text { Non Exposure } \\
\text { Group }\end{array}$} \\
\cline { 2 - 5 } & $\mathbf{n}$ & $\mathbf{\%}$ & $\mathbf{N}$ & $\mathbf{\%}$ \\
\hline Source & \multicolumn{4}{|c|}{} \\
\hline Community & 5 & 25.3 & 8 & 21.1 \\
\hline Government & 14 & 73.7 & 30 & 78.9 \\
\hline Total & 19 & 100.0 & 38 & 100.0 \\
\hline Availability & \multicolumn{5}{|}{} \\
\hline Yes & 18 & 94.7 & 34 & 89.5 \\
\hline No & 1 & 5.3 & 4 & 10.5 \\
\hline Total & 19 & 100.0 & 38 & 100.0 \\
\hline
\end{tabular}

Descriptive Analysis for Process Components from the My Village My Home: Data sources for filling in MVMH at the beginning were cohort books, auxiliary books, Health Towards Cards and Baby \& Mom's books as well as reports from the community and house-tohouse visits.

Table 5: Distribution of Data Source for MVMH in Surabaya, 2018

\begin{tabular}{|c|c|c|c|c|}
\hline \multirow{2}{*}{ Data Source } & \multicolumn{2}{|c|}{$\begin{array}{c}\text { Exposure } \\
\text { Group }\end{array}$} & \multicolumn{2}{c|}{$\begin{array}{c}\text { Non Exposure } \\
\text { Group }\end{array}$} \\
\cline { 2 - 5 } & $\mathbf{n}$ & $\mathbf{\%}$ & $\mathbf{n}$ & $\mathbf{\%}$ \\
\hline Door to door & 8 & 42.1 & 18 & 47.4 \\
\hline Community & 4 & 21.1 & 12 & 31.6 \\
\hline Cohort book & 3 & 15.8 & 5 & 13.2 \\
\hline Help book & 6 & 31.6 & 11 & 28.9 \\
\hline Health Towards Cards & 15 & 78.9 & 34 & 89.5 \\
\hline Baby \& Mom's books & 7 & 36.8 & 26 & 68.4 \\
\hline
\end{tabular}


The results showed that most Posyandu cadres in both groups said that filling in the MVMH for infants and children who did immunization at the Posyandu was at the end of every Posyandu activity. Filling the MVMH should be every time a newborn is born and every baby or child is immunized.

In the group of cadres who had received training, most said that monitoring of immunization schedules for immunized infants and children in Posyandu and Puskesmas was close to the Posyandu schedule (68.4\%). While in the cadre group who did not receive training, most said that monitoring of immunization schedules for infants and children immunized in Posyandu and puskesmas was during the implementation of Posyandu $(57.9 \%)$. More information is presented in table 6 .

In the group of cadres who had received training, most said that monitoring of immunization schedules for infants and children immunized not at Posyandu was close to the immunization schedule $(68.4 \%)$. Whereas in the group of cadres who did not receive training, (52.6\%) cadres said that monitoring of immunization schedules for immunized infants and children was not in Posyandu, namely during the implementation of Posyandu.

Table 6: The Frequency Distribution Monitoring of Infant and Child Immunization Schedules Immunization at Posyandu and at the Puskesmas in Surabaya, 2018

\begin{tabular}{|c|c|c|c|c|}
\hline \multirow{2}{*}{ Frequency } & \multicolumn{2}{|c|}{ Exposure Group } & \multicolumn{2}{c|}{ Non Exposure Group } \\
\cline { 2 - 5 } & $\mathbf{( n )}$ & $\mathbf{( \% )}$ & $\mathbf{( n )}$ & $\mathbf{( \% )}$ \\
\hline Each approaching the Posyandu schedule & 2 & 10.5 & 12 & 31.6 \\
\hline During the implementation of the Posyandu & 14 & 73.7 & 21 & 55.3 \\
\hline Never & 1 & 5.0 & 5 & 13.2 \\
\hline Total & 19 & 100.0 & 19 & 100.0 \\
\hline
\end{tabular}

Table 7: The Frequency Distribution of of Cadre's Activity to Record Immunization Data from Cohort Book to MVMH in Surabaya, 2018

\begin{tabular}{|c|c|c|c|c|}
\hline \multirow{2}{*}{ Frequency } & \multicolumn{2}{|c|}{ Exposure Group } & \multicolumn{2}{c|}{ Non Exposure Group } \\
\cline { 2 - 5 } & $\mathbf{( n )}$ & $\mathbf{( \% )}$ & $\mathbf{( n )}$ & $\mathbf{( \% )}$ \\
\hline Every time a newborn is born and each baby is immunized & 9 & 47.4 & 12 & 31.6 \\
\hline At the end of Posyandu activities & 9 & 47.4 & 23 & 71.9 \\
\hline End of month & 0 & 0 & 3 & 7.9 \\
\hline Never & 1 & 5.3 & 0 & 0 \\
\hline Total & 19 & 100.0 & 38 & 100.0 \\
\hline
\end{tabular}

\section{Discussion}

Immunization are important to reduce vaccinepreventable diseases in children, and consistent control of vaccine-preventable diseases depends on fairly high immunization coverage ${ }^{10)}$.

A person's behavior is influenced by 3 factors, they are predisposing factors, reinforcing factors, enabling factors. One of the predisposing factors that influence health behavior is knowledge. It is the basic foundation of attidudes and positive action of a person ${ }^{11}$. It means that a person good knowledge would showed that attitude good. A person's knowledge is very influential on the actions they take. Knowledge is the result of knowing something and knowledge occurs after someone senses a particular object. The sensation can be through the senses of sight, hearing, smell, taste, and touch. Most human knowledge is obtained through the ears and eyes ${ }^{12}$.

Knowledge of cadres and mothers of toddlers about MVMH was measured by 8 questions about the description of the contents of the MVMH, those who played an active role in the MVMH, as well as the goals and benefits of the MVMH. Cadre in heath volunteers, selected by the community, most of active cadres entirely female, although it may be a cadre of men ${ }^{13)}$. Mostly, training cadres or without training have MVMH good training.

Most of the baduta mothers accompanied with cadres with training have known about the MVMH while for mothers with cadres without training, $50 \%$ of mothers 
do not know the MVMH. Most of the respondents who knew about the MVMH had sufficient knowledge about MVMH both for mothers with cadre with and without trainings. The 8 questions that were asked to the mother of baduta mostly answered incorrectly, this questions related to the purpose and benefits of the MVMH. One of question, namely "The home of immunization can be used as a means of communication between midwives, cadres, and the community regarding immunization" and "The MVMH provides an illustration of infant immunization status at the posyandu only". There is a significant difference between mothers and cadres who have received training and mothers with cadres who do not receive training are related to whether or not the MVMH is available.

They inform and motivate about immunization to mothers and fathers during their regular visits as well as in meetings and other community activities. Although rarely needed, they also do home visits to motivate the parents of a child who has fallen behind in his/her immunizations.

The results showed that both cadres and mothers had good knowledge about MVMH because they had to be in every Posyandu while maintaining the existence and sustainability of the MVMH method therefore 3 all under-aged children were immunized in order to improve the Complete Basic Immunization Program in Surabaya. The level of vaccination coverage in a given comunity depends on both service factors and the degree to which the public understans and trusts the immunization process ${ }^{6}$.

\section{Conclusion}

Most of the cadres and mothers who are either in the group of cadres who have received training or who have not received training have good knowledge. Most cadres and mothers both in the group of cadres who have received training or who have not received training have a good attitude towards the MVMH.

\section{Recommendation}

The results showed that both cadres and baduta mothers had good knowledge about MVMH because they had to be in every Posyandu while maintaining the existence and sustainability of the MVMH method therefore 3 all under-aged children were immunized in order to improve the Complete Basic Immunization Program in Surabaya.

Conflict of Interest: The authors have no conflicts of interest associated with the material presented in this paper.

Source of Funding: This research was supported by Faculty of Public Health Universitas Airlangga and District of Health, Surabaya, Indonesia.

Ethical Clearance: Received from Health Research Ethics Committee, Faculty of Public Health, Universitas Airlangga.

\section{REFERENCES}

1. Ministry of Health Republic of Indonesia. Indonesian Health Profile in 2015. Jakarta. 2015.

2. Syahrul, Fariani., Djazuly C., Diah I., Arief H., Kurnia D.A., Hario M. Independent Evaluation of MR Immunization Coverage at East Java Province, Indonesia 2017. WHO-Ministry of Health Republic of Indonesia-Universitas Airlangga-Universitas Indonesia.2018.

3. Health District Surabaya. Report of Baseline Data Survey: Basic Complete Immunization Problem at Non UCI Area in Surabaya, 2015. Surabaya.2015.

4. Holipah, Asri M and Yoshiki, K. Determinants of Immunization status among 12-to 23-month-old children in Indonesia (2008-2013) : a multilevel analysis. BMC Public Health. 2018:18:288.

5. Nomhwange, Terna I., Faisal S., Fiona B., Sambo G., Usma K., Gregory, Sisay GT., Bassey O., and Chima O. Routine Immunization Community Surveys as a Tool for Guiding Program Implementation in Kaduna State, Nigeria 20152016. BMC Public Health. 2018 : 18 (Suppl. 4): 1313

6. Jain, M., Gunjan Taneja, Ruhul Amin, Robert Steinglass, Michael Favine. Engaging Communities With a Simple Tool to Help Increase Immunization Coverage. Global Health: Scince and Practice. 2015: Volume 3, Number 1;117-125.

7. World Health Organization. State of The World's Vaccines and Immunizations. World Health Organization, UNICEF, World Bank. Geneva. 2009. 
8. USAID. My Village My Home : A Tool to Optimize Immunization Coverage. Guidance Note for Using The MVMH Tool. 2014 (June).

9. Tsega, Asnakew., Michael Favin. My Village My Home: A Tool That Helps Communities Track Vaccinations of Individual Infants. USAID, 2018 (May).

10. Uskum, Ersin, Suha, BU., Moral U., and Mohmet Y. Effectiveness of a Training Intervention on Immunization to Increase Knowledge of Primary Healthcare Workers and Vaccination Coverage Rates. Public Health. Volume 122. Issue 9. September 2008: 949-958.
11. Notoatmodjo, Soekidjo. Education of Health and Behavior Sciences. Jakarta.2012.

12. World Health Organization. World Health Statistic Report 2015. Geneva: World Health Organization. 2015.

13. Solikhah, Umi., Hari K., Fitri H. Health Cadres Commintmentin Child Health Care in Moslem Society of Banyumas District. Proceeding on International Conference on Economics, Education, and Cultural Development of Moslem Society in ASEAN, 2016: Volume 1, 60-65. 